\section{Preharvest Peroxyacetic Acid Sprays Slow Decay and Extend Shelf Life of Strawberries}

\author{
J.A. Narciso ${ }^{1}$, E.A. Baldwin, A. Plotto, and C.M. Ference \\ USDA-ARS, Citrus \& Subtropical Products Laboratory, 600 Avenue S, N.W., \\ Winter Haven, FL 33881
}

Additional index words. Fragaria $\times$ ananassa, Botrytis cinerea, Rhizopus stolonifer, storage, postharvest

\begin{abstract}
Strawberry is an important fruit crop in Florida. Yearly losses can be attributed to pre- and postharvest decay incited by Botrytis cinerea $\mathbf{P}$. Micheli ex Pers. and postharvest decay resulting from primarily Rhizopus stolonifer (Ehrenb. ex Fr.) Vuillemin. In this study, the sanitizer peroxyacetic acid $\left(100 \mu L \cdot L^{-1}\right)$ was sprayed on flowers and developing strawberries 1, 2, and $3 \mathrm{~d}$ preharvest. Most of the time, fruit sprayed 3 days before harvest had significantly less decay than fruit sprayed 1 day preharvest or not sprayed when stored at $18{ }^{\circ} \mathrm{C}$. Strawberries sprayed in the field with peroxyacetic acid and then coated postharvest with $1 \%$ chitosan coating had reduced decay compared with fruit only treated preharvest with peroxyacetic acid (PAA) for up to 12 days in storage. Sensitivity of $B$. cinerea hyphae and conidia to PAA was shown by the presence of a zone of inhibition using the disc assay method.
\end{abstract}

The United States is the largest producer of strawberries (U.S. Dept. of Agriculture, 2005) with Florida second only to California in strawberry production. Strawberries have high levels of antioxidants (Wu et al., 2004) and are under increasing demand by consumers. Strawberries are extremely fragile and perishable necessitating minimal handling after harvest (Mitcham and Mitchell, 2002). For this reason, strawberries are harvested and packed in the field directly into retail clamshell containers that are delivered to the supermarket. Any treatment to reduce decay of strawberries would best be done as a preharvest operation to fit the current industrial harvesting and handling practices. Postharvest decay treatments to strawberries would only be accepted by the industry if decay reduction and resulting shelf life extension were very significant, justifying a change in the current harvesting and handling operation. However, postharvest treatments could increase shelf life of processed strawberries for the cut fruit industry. In most cases, any postharvest handling of strawberries leads to injury, which provides increased

\footnotetext{
Received for publication 31 Oct. 2006. Accepted for publication $12 \mathrm{Feb} .2007$.

Mention of a trademark or proprietary product is for identification only and does not imply a guarantee or a warranty of the product by the U.S. Dept. of Agriculture. The U.S. Dept. of Agriculture prohibits discrimination in all its programs and activities on the basis of race, color, national origin, gender, religion, age, disability, political beliefs, sexual orientation, marital or family status.

This research is based on work supported by the Florida Strawberry Association.

${ }^{1}$ To whom reprint requests should be addressed; e-mail jan@citrus.usda.gov
}

opportunity for wound pathogens and enhances decay.

Strawberry losses resulting from diseases are often difficult to quantify because of plant cultivar and cultural practices, which vary with locality, handling, storage, and marketing (Maas, 1980). Fungi are significant pre- and postharvest decay organisms for strawberries. Botrytis berry rot (causal organism, Botrytis cinerea) causes both pre- and postharvest disease. It often initiates infection in the field at the flowering or young fruit stage, often remaining latent until postharvest (Blacharski et al., 2001; Maas, 1980; U.S. Dept. of Agriculture, 2005). Botrytis is a facultative saprophyte producing a repeating cycle of asexual spores on senescent tissues, diseased flowers or fruit that are dispersed to young plant tissues by rain, wind, or insects (Blacharski et al., 2001; Maas, 1980).

More important as postharvest than preharvest pathogens are Rhizopus stolonifer and Mucor spp., Zygomycetes, commonly found in soil. These fungi are wound parasites and can become established on ripe fruit within $12 \mathrm{~h}$ (Maas, 1980). Although preharvest applications of fungicides have been shown to increase yields and decrease postharvest decay incited by $B$. cinerea, $R$. stolonifer and related opportunistic organisms are not well-controlled by preharvest fungicidal sprays. Most fungicides are residual on the fruit/plant, and because they are still present, fungi can acquire resistance to them rendering them ineffective (Maas, 1980; Maas and Smith, 1972). Additionally, synthetic fungicides are not acceptable for the organic market.

After harvest, refrigeration is most commonly used to slow decay in strawberries and maintain quality (El Ghaouth et al., 1991; Maas, 1980; Nunes et al., 2002). Most fungi- cides cannot maintain strawberry quality without the aid of refrigeration (Blacharski et al., 2001). In addition to preharvest treatments, postharvest applications of films and coatings such as chitosan act as antimicrobial agents while maintaining fruit quality (El Ghaouth et al., 1991, 1992, 1997; U.S. Dept. of Agriculture, 2005). For organic fruit, use of acidic vapors, food additives, and water dips offer some protection from decay (Karabulut et al., 2004; Park et al., 2005; Sholberg et al., 2000).

While postharvest surface treatments may delay decay, keeping spores from developing on plant tissues while in the field is most efficacious (Blacharski et al., 2001; Maas, 1980; Maas and Smith, 1972; U.S. Dept. of Agriculture, 2005). Our primary objective was to lengthen shelf life of strawberries by using the nonresidual commercial disinfectant, peroxyacetic acid (PAA) as an antimicrobial preharvest spray to reduce postharvest decay. Postharvest coatings were also applied to the fruit surface to enhance the antimicrobial control of the preharvest application of PAA. This disinfectant/sanitizer is soon to be approved for the organic market and has been shown to be effective against postharvest decay when applied postharvest on mango and citrus (Narciso, 2005; Narciso and Plotto, 2005).

\section{Materials and Methods}

Experimental strawberry plants, Fragaria xananassa Duchesne, variety 'Strawberry Festival', were located at the Florida Strawberry Growers Research and Education Center in Dover, Fla. Plants were in a commercial field in a double-row bed with $30.5-\mathrm{cm}$ spacing between rows. Water and fertilizer were provided through drip tape after initial overhead irrigation after transplanting. The rows were $\approx 74 \mathrm{~m}$ long and each row was divided into six blocks with 54 to 57 plants in each block. A buffer area of $\approx 0.61 \mathrm{~m}$ at the start and the end of each row was used to better isolate experimental plants from open areas. Studies on strawberry plants in this field began in Jan. 2006.

Spraying. Before spraying, ripe strawberries were harvested from all plants in the experimental areas including control (nonsprayed) blocks. This left only flowers and very young strawberries, which would result in fruit that were synchronized in ripening. Commercial PAA (OxiDate; BioSafe Systems, Glastonbury, Conn.) was mixed on-site $\left(100 \mu \mathrm{L} \cdot \mathrm{L}^{-1}\right)$ in 8 -L hand-sprayers (Chapin, Batavia, N.Y.). Spraying took place $3 \mathrm{~d}, 2 \mathrm{~d}$, and $1 \mathrm{~d}(3 \mathrm{~S}, 2 \mathrm{~S}$, and $1 \mathrm{~S})$ before harvesting the fruit from the experimental rows (e.g., $3 \mathrm{~S}$ fruit were harvested the morning of the fourth day after spraying, leaving plant in "contact" with the spray for $3 \mathrm{~d}$ ). Three days before the first harvest, the first blocks of each of two experimental rows was sprayed (3S) with $14 \mathrm{~L}$ of PAA per one block area using a heavy mist setting and completely covering all surfaces and all parts of the plant. Plants were not resprayed during the course of each 
experiment. Handheld plastic barriers were used to prevent spray from drifting to unsprayed areas. The next day, the spray protocol was repeated and again on the third day. Three days after the initial spray, all the ripe strawberries in the experimental spray and nonsprayed areas were harvested. The strawberries were picked with gloved hands and placed directly into polyethylene terephthalate $325-\mathrm{mL}$ vented clamshell containers (Pactiv Corp., Lake Forest, Ill.), 10 fruit per container, six to 15 containers per treatment, similar to commercial operations. The clamshells were packed in plastic crates and taken back to the Citrus and Subtropical Products Laboratory in Winter Haven. The strawberries were stored at $5{ }^{\circ} \mathrm{C}$ overnight to remove field heat and then moved to an $18{ }^{\circ} \mathrm{C}$ storage room with $95 \%$ relative humidity $(\mathrm{RH})$. Temperature and humidity were monitored by dataloggers (Dickson Pro Series; Dickson, Addison, Ill.). Decay was evaluated every few days; strawberries were considered decayed when $30 \%$ or more of the surface was covered with lesions or there was visible mycelium. This process of spraying and evaluating decay was repeated three times in Jan., Feb., and Mar. 2006.

Determination of microbial load on immature fruit. A study of the effect of PAA on the microbial load of developing fruit was made concurrently with the Mar. 2006 spray experiment. On the first day of spraying ( $3 \mathrm{~d}$ before harvest), immature strawberry samples (green to white color stage) were randomly picked from each of the three experimental blocks (spray areas) and placed into sterile WhirlPak bags (Nasco, Modesto, Calif.), five fruit per bag, four bags per experimental block. The bags were placed in a cooler and taken back to the laboratory where they were weighed. After weighing, $99 \mathrm{~mL}$ of sterile phosphate buffer $(\mathrm{pH} 7.2)$ was added to each bag and the strawberries and the buffer were manually agitated for 2 min to remove the microflora from the surface of the fruit. The buffer was analyzed for presence of any microorganisms removed from fruit surfaces by using the protocol described by Narciso and Plotto (2005).

Weather. Averages of weather parameters during the duration of each study such as air temperatures $(60 \mathrm{~cm}$ above the surface of the soil), precipitation, wind speeds, and solar radiation were evaluated to better understand differences in field results. Weather data were obtained from the Florida Automated Weather Service, Dover Station (State of Florida, 2006).

Postharvest treatments. In Mar. 2006, experimental blocks were sprayed $3 \mathrm{~d}$ preharvest with a $100 \mu \mathrm{L} \cdot \mathrm{L}^{-1}$ solution of PAA following the protocol previously described. On harvest day, $\approx 300$ strawberries from plants sprayed $3 \mathrm{~d}$ earlier were picked and placed in a clean container. Three hundred fruit were also picked from the corresponding no-spray (control) group of plants and placed in a separate container. Strawberries were taken back to the laboratory, sorted, and stored at $5{ }^{\circ} \mathrm{C}$ until treated.
Previously sprayed and nonsprayed stored strawberries were divided into four groups of 10 per treatment. Postharvest treatments were manually sprayed onto fruit using 250-mL misters (Fisher Scientific, Atlanta). There were five treatments applied to strawberries harvested from sprayed and nonsprayed sections of the field: no-treatment, distilled water, $50 \mu \mathrm{L} \cdot \mathrm{L}^{-1}$ PAA (a formulation of PAA rated for postharvest use; StorOx; BioSafe Systems, Glastonbury, Conn.), chitosan $(0.1 \%$ in $0.5 \%$ glacial acetic acid; FranceChitine, Orange, France), and sodium propionate $(0.5 \%$; Avocado Research Chemicals, Ltd., Lancashire, U.K.). The strawberries were spread on plastic mesh (commercial mesh size $0.9 \times 1.3 \mathrm{~cm}$ ) stretched between $30.5 \times 30.5-\mathrm{cm}$ polyvinyl chloride frames to allow the treatments to drain and the fruit to dry. After drying, strawberries were placed into containers as described previously, 10 fruit per container. The fruit were stored at $18{ }^{\circ} \mathrm{C}$ at $95 \% \mathrm{RH}$. Decay was logged as previously described.

Determination of pathogen sensitivity to peroxyacetic acid and chitosan. To test the effect of PAA on B. cinerea and $R$. stolonifer spores, the disc assay method was used. Spores were collected from plates of $B$. cinerea or $R$. stolonifer. Organisms were grown on potato dextrose agar for 5 to $7 \mathrm{~d}$ at $25^{\circ} \mathrm{C}$. Spores were removed from the colony surface with a solution of sterile water and $0.1 \%$ Tween 20 while gently rubbing the plate surface with a sterile glass rod. Spores were filtered through three layers of cheesecloth and adjusted to $\approx 3.0 \times 10^{5}$ spores $/ \mathrm{mL}$ with a hemocytometer (Hausser Scientific, Horsham, Penn.). Two hundred fifty microliters of inoculum of either $B$. cinerea or $R$. stolonifer was placed on the surface of potato dextrose agar plates and evenly spread with a sterile glass rod. Four sterile filter paper discs (10.5 mm) (Ace Glass, Vineland, N.J.) were placed in a container with a solution of $100 \mu \mathrm{L} \cdot \mathrm{L}^{-1}$ PAA and swirled for $30 \mathrm{~s}$. The discs were drained, removed with sterile forceps, and placed on the surface of the inoculated plates. Plates were incubated at $25{ }^{\circ} \mathrm{C}$ for 10 to $14 \mathrm{~d}$.

Determination of sensitivity of Botrytis to chitosan coating. Effect of chitosan on growth of $B$. cinerea was determined using the same method described previously. The discs were placed in $0.1 \%$ chitosan in $0.5 \%$ glacial acetic acid for $30 \mathrm{~s}$ and placed on plates coated with the $B$. cinerea inoculum. The chitosan buffer was also tested.

Statistical analysis. The Wilcoxon ranksum test for difference in medians and equal variance ( $t$ test) and the Kruskal-Wallis test were used to determine significance between decay rates of the different spray groups and the average decay of the nonspray group. Tests were based on data distribution (Number Cruncher Statistical System, Kaysville, Utah; and SAS System Software Version 9.1; SAS Institute, Cary, N.C.) with $P \leq 0.05$ designated as significance of difference.

\section{Results and Discussion}

Designations are S for sprayed NS for nonsprayed strawberries. The $3 \mathrm{~S}$ fruit were sprayed $3 \mathrm{~d}$ before harvest, $2 \mathrm{~S}$ fruit were sprayed $2 \mathrm{~d}$ before harvest, and $1 \mathrm{~S}$ fruit were sprayed the day before harvest.

In January, two experimental groups were picked within $3 \mathrm{~d}$ of each other and designated as harvest 1 and 2. Decay rates over the postharvest storage period (days after harvest) are summarized for the two January harvests. For harvest $1,16 \mathrm{~d}$ postharvest, $3 \mathrm{~S}$ strawberries had significantly (Figs. 1 and 2A) less decay $(20 \%)$ than NS strawberries $(50 \%)$, whereas $2 \mathrm{~S}$ and $1 \mathrm{~S}$ strawberries had $35 \%$ and $63 \%$ decay, respectively, and were not significantly different from the average NS decay rate of $50 \%$. However, $17 \mathrm{~d}$ after harvest, both $3 \mathrm{~S}$ and $2 \mathrm{~S}$ strawberries had

January

\begin{tabular}{|c|c|c|c|c|c|c|}
\hline \multirow{3}{*}{ Harvest 1: } & & Day 14 & Day 16 & Day 17 & Day 20 & Day 24 \\
\hline & $3 S$ & NS & $x$ & $x$ & NS & NS \\
\hline & $2 S$ & NS & NS & $x$ & NS & NS \\
\hline & $1 \mathrm{~S}$ & NS & NS & NS & NS & NS \\
\hline & & Day 11 & Day 13 & Day 14 & Day 17 & Day 21 \\
\hline Harvest 2: & 35 & NS & $x$ & $x$ & $x$ & NS \\
\hline & $2 S$ & NS & $x$ & $x$ & NS & NS \\
\hline & 15 & NS & NS & NS & NS & NS \\
\hline
\end{tabular}

Eebruary

Exp. 1:

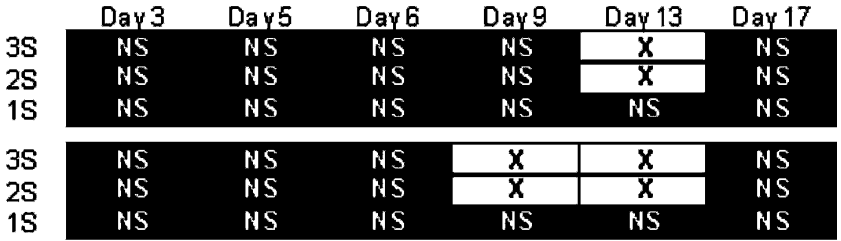

March

\begin{tabular}{|c|c|c|c|c|c|}
\hline Dav 7 & Darg & Day 11 & Day 15 & Day 17 & Day 19 \\
\hline NS & $x$ & $x$ & $x$ & $x$ & NS \\
\hline NS & $\bar{x}$ & $\bar{x}$ & $\bar{x}$ & $\bar{x}$ & NS \\
\hline NS & $\bar{x}$ & $\bar{x}$ & $\bar{x}$ & $\bar{x}$ & NS \\
\hline
\end{tabular}

Fig. 1. Chart showing significance between decay rates in sprayed and control (unsprayed) strawberries during 17 to $24 \mathrm{~d}$ in storage. NS means no significance and $\mathbf{X}$ shows significance between the sprayed and nonsprayed populations of the same day: $3 \mathrm{~S}=$ sprayed $3 \mathrm{~d}$ preharvest; $2 \mathrm{~S}=$ sprayed $2 \mathrm{~d}$ preharvest; $1 \mathrm{~S}=$ sprayed $1 \mathrm{~d}$ preharvest; NS $=$ not sprayed 

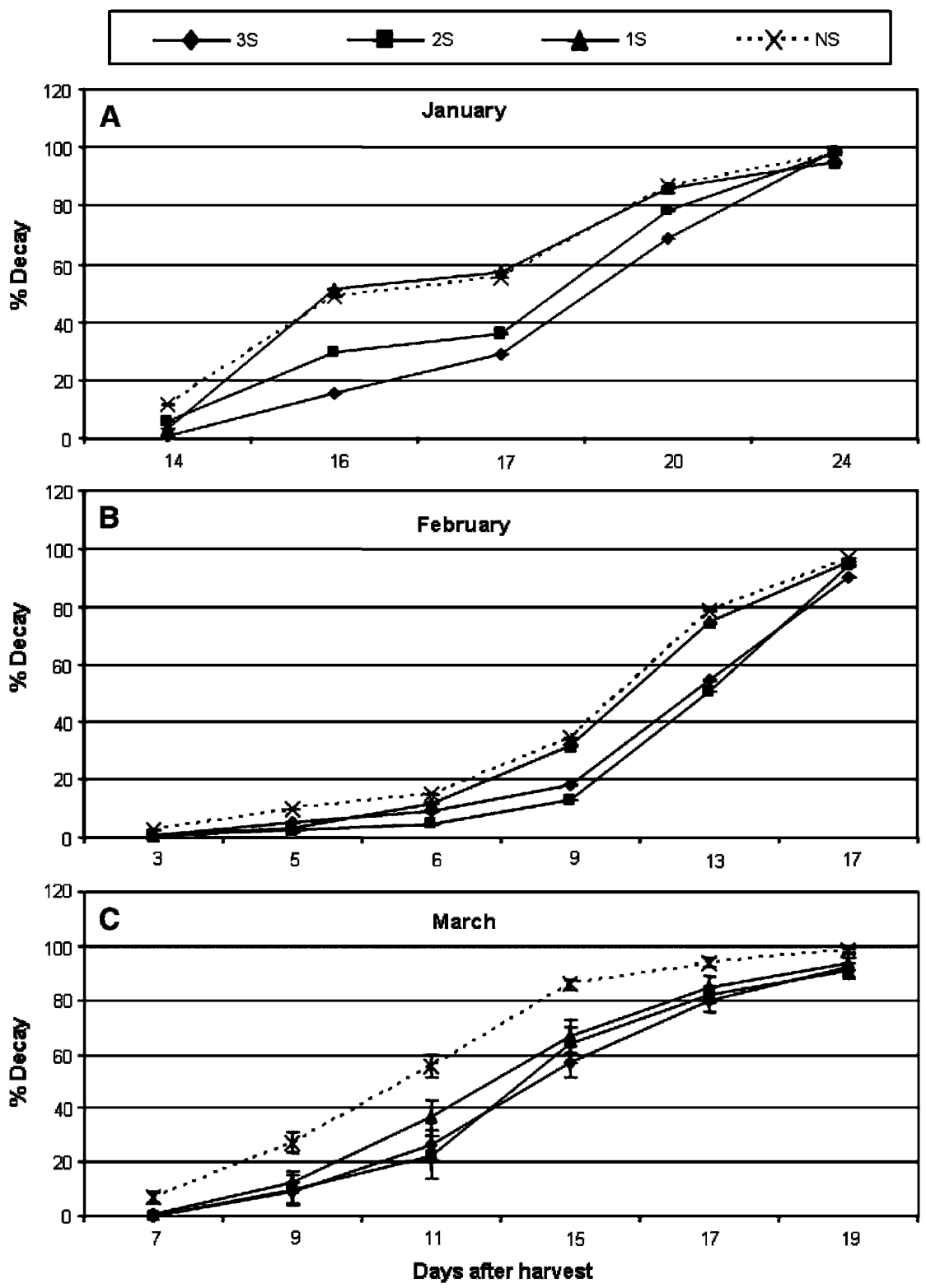

Fig. 2. Decay rates of strawberries in clamshells stored at $18{ }^{\circ} \mathrm{C}$ for up to $24 \mathrm{~d}$ : $3 \mathrm{~S}$ (sprayed $3 \mathrm{~d}$ preharvest); $2 \mathrm{~S}$ (sprayed $2 \mathrm{~d}$ preharvest,); $1 \mathrm{~S}$ (sprayed $1 \mathrm{~d}$ preharvest); $\mathrm{NS}=$ not sprayed. Data $\pm \mathrm{SE}$ (if error bars are not visible then are under the symbol) are a summary of duplicated experiments in (A) January for two harvest dates (20 and 23 Jan. 2006) and (B) 24 Feb. 2006 for two areas of the field and a (C) single experiment on 10 Mar. 2006. Six to 12,11 to 15 , and 14 to 17 clamshells with 10 strawberries each for January, February, and March, respectively, were counted per treatment in each experiment.

significantly less decay $(37 \%$ and $42 \%$, respectively) than the NS group (60\%). Twenty days postharvest, all sprayed groups had decay that was not different from the NS group.

Data from harvest 2 in January showed similar results. Thirteen days postharvest, $3 \mathrm{~S}$ and $2 \mathrm{~S}$ spray strawberries had significantly (Fig. 1) less decay ( $12 \%$ and $21 \%$, respectively) than the $1 \mathrm{~S}(43 \%)$ or the NS group (48\%). Seventeen days postharvest, only the $3 \mathrm{~S}$ group had less decay than the NS group. For both January trials, those strawberries sprayed $3 \mathrm{~d}(3 \mathrm{~S})$ before harvest had slightly less decay than the $2 \mathrm{~S}$ group and significantly slower rates of decay than the $1 \mathrm{~S}$ and NS groups.

For the combined January data, the $2 \mathrm{~S}$ and $3 \mathrm{~S}$ strawberries exhibited less decay for 16 to $20 \mathrm{~d}$ in storage compared with the 1S and NS fruit, with the $3 \mathrm{~S}$ group being most resistant to postharvest decay. Weather parameters for these trials showed temperatures at $60 \mathrm{~cm}$ above the surface of the soil with an average high of $22.6{ }^{\circ} \mathrm{C}$ and average low temperature of $5.9^{\circ} \mathrm{C}$ with negligible rain and intermittent sun $\left(163 \mathrm{w} \cdot \mathrm{m}^{-2}\right)$.

In February, there were two experimental groups picked from different sectors of the commercial field: Expt. 1 contained interior blocks protected from open spaces and Expt. 2 contained exterior blocks at the edge of the field. Decay rates over the postharvest storage period (days after harvest) are summarized for the two field locations for February in Figure 2B. Data for Expt. 1 (blocks from the interior of the field) showed no significant difference in decay between sprayed and nonsprayed strawberries until $13 \mathrm{~d}$ after harvest (Fig. 1). After $13 \mathrm{~d}, 3 \mathrm{~S}$ and $2 \mathrm{~S}$ groups had less decay (67\% and $48 \%$, respectively) than the $1 \mathrm{~S}(80 \%)$ and the NS (81\%) groups (Fig. 1). After $17 \mathrm{~d}$, all groups had decay greater than $90 \%$.

Data for Expt. 2 (blocks from the edge of the field) were comparable to Expt. 1 with the exception that decay was slower in all groups. Nine days postharvest, $3 \mathrm{~S}$ and $2 \mathrm{~S}$ had less decay ( $8 \%$ and $4 \%$, respectively) than the $1 \mathrm{~S}$ (27\%) and the NS (27\%) groups. Thirteen days postharvest, the $3 \mathrm{~S}$ and $2 \mathrm{~S}$ groups remained significantly (Fig. 1) less decayed (39\% and $53 \%$, respectively) than the $1 \mathrm{~S}$ $(68 \%)$ and NS (77\%) groups.

For the combined February data, the $2 \mathrm{~S}$ and $3 \mathrm{~S}$ strawberries exhibited less decay for 9 and $13 \mathrm{~d}$ in storage compared with the $1 \mathrm{~S}$ and NS fruit. Weather data for this time period showed temperatures with an average high of $20.0^{\circ} \mathrm{C}$ and average low of $16.0^{\circ} \mathrm{C}$ at $60 \mathrm{~cm}$ above the soil surface with negligible rain and intermittent sun $\left(159 \mathrm{w} \cdot \mathrm{m}^{-2}\right)$. Wind speeds, as would have affected the exterior block, were between 0.9 and 1.8 $\mathrm{m} \cdot \mathrm{s}^{-1}$. Although the actual decay rates were different between the January and February experimental groups, the strawberries that were sprayed $3 \mathrm{~d}$ before harvest had the slowest decay rates followed by the $2 \mathrm{~S}$ group. Those strawberries sprayed the day before harvest did not show any difference in decay rates when compared with the nonsprayed group.

Data for March show decay rates for all three spray groups $(3 \mathrm{~S}, 2 \mathrm{~S}$, and $1 \mathrm{~S})$ were significantly less than those of the NS group (Figs. 1 and 2C). Nine days postharvest, percent decay of $3 \mathrm{~S}, 2 \mathrm{~S}$, and $1 \mathrm{~S}$ was $9 \%$, $10 \%$, and $13 \%$, respectively, whereas the NS group was $28 \%$. At $17 \mathrm{~d}$ postharvest, decay for the sprayed fruit was still less $(3 \mathrm{~S}=80 \%$, $2 \mathrm{~S}=82 \%$, and $1 \mathrm{~S}=85 \%$ ) than the NS group (94\%). Temperatures for March at $60 \mathrm{~cm}$ above the soil surface ranged from an average high of $25^{\circ} \mathrm{C}$ to a low of $10{ }^{\circ} \mathrm{C}$. One cold night $\left(4.6{ }^{\circ} \mathrm{C}\right)$ offset a general increase in temperatures. Precipitation was minimal but there were several sunny days $\left(244 \mathrm{w} \cdot \mathrm{m}^{-2}\right)$.

In summary, data for the months of January and February show that strawberries sprayed 3 d preharvest had reduced decay when compared with strawberries sprayed $1 \mathrm{~d}$ preharvest or not sprayed, and all sprayed treatments had reduced decay compared with those not sprayed in March.

Microflora on immature fruit. To understand what seemed to be a residual effect of PAA on strawberry decay organisms, green fruit were daily assessed for surface microflora populations. Data show a continuing decline in microbial populations after the initial spray when compared with the initial nonsprayed plants (Fig. 3). Microorganisms on the surface of the immature strawberries were significantly reduced in the $3 \mathrm{~S}$, $2 \mathrm{~S}$, and the $1 \mathrm{~S}$ groups up to $3 \mathrm{~d}$ postspray (Fig. 3).

PAA is volatile, breaking down to release oxygen and acetic acid, but as a compound is 
not residual on fruit surfaces. The data from the immature strawberry study suggest that it continues to reduce microbial populations after initial application. This would indicate that over time, the number of organisms on the fruit surfaces decrease as a result of cell would be unable to make repairs while remaining on the now acidified environment of the strawberry surface. Immature strawberries showed a continued decline in the microbial population after spraying, which corresponds with ripe strawberry studies. Strawberries sprayed 3 or 2 d preharvest had significantly lower rates of decay than fruit sprayed just before harvest or not sprayed, likely as a result of a reduction in microorganisms and, subsequently, their growth.

Determination of pathogen sensitivity to peroxyacetic acid. Evidence of sensitivity of $B$. cinerea hyphae and conidia to PAA was shown by the presence of a zone of inhibition $(\approx 1 \mathrm{~cm})$ around each of the discs after $5 \mathrm{~d}$ growth. After $10 \mathrm{~d}$, the inhibition area was still obvious, although $B$. cinerea hyphae were beginning to move closer to the discs (Fig. 4). R. stolonifer was not as sensitive as $R$. stolonifer growth in PAA plates was almost as dense as in the control. The only indication that PAA had any effect on parts of the plate that had exposure to PAA (Fig. 5). The disc assay study served as an indicator of the possible reduction of growth of $B$. cinerea and $R$. stolonifer by PAA when

Postharvest treatments. To determine if postharvest antidecay treatments could enhance the decay reduction obtained with death when exposed to PAA. Sublethal cells $B$. cinerea to the presence of PAA. After $10 \mathrm{~d}$, $R$. stolonifer was decreased sporulation over applied on strawberries in the field.

the preharvest PAA sprays, strawberries sprayed with PAA 3 d preharvest and strawberries from corresponding nonsprayed blocks were harvested, brought to the laboratory, and treated with postharvest antidecay compounds or coatings, including a lower (approved for postharvest application) concentration of PAA (Table 1). The preharvest PAA-sprayed strawberries with the postharvest spray treatment had generally less decay than nonsprayed fruit with postharvest treatments, except for sodium propionate, after $12 \mathrm{~d}$ (Table 1). This was significant for "no postharvest treatment" day 6; postharvest water treatment, day 12; and the postharvest chitosan treatment, days 6 to 12. Chitosan coating on presprayed fruit significantly reduced decay ( $17.5 \%$ decay) for $8 \mathrm{~d}$ longer than the control (no preharvest spray or postharvest treatment, $62.5 \%$ decay) (Table 1). Potato dextrose plates containing $10 \mathrm{~d}$ $B$. cinerea cultures and filter discs with chitosan or its buffer showed no difference in fungal growth when compared with the control plates (Fig. 4), indicating that chitosan did not have a direct effect on the pathogen but may have protected the fruit by eliciting a plant defense response (Kendra and Hadwigr, 1984). Other studies have reported chitosan to damage fungal hyphae (El Ghaouth et al., 1997).

Studies by other workers have also shown that chitosan is effective in extending the shelf life of strawberries (El Ghaouth et al., 1991; 1992; Park et al., 2005). Data in Table 1 show that on some strawberries, exposure to PAA preharvest before further treatment reduced postharvest decay. PAA reduces microflora populations on the fruit. As an additional postharvest treatment,

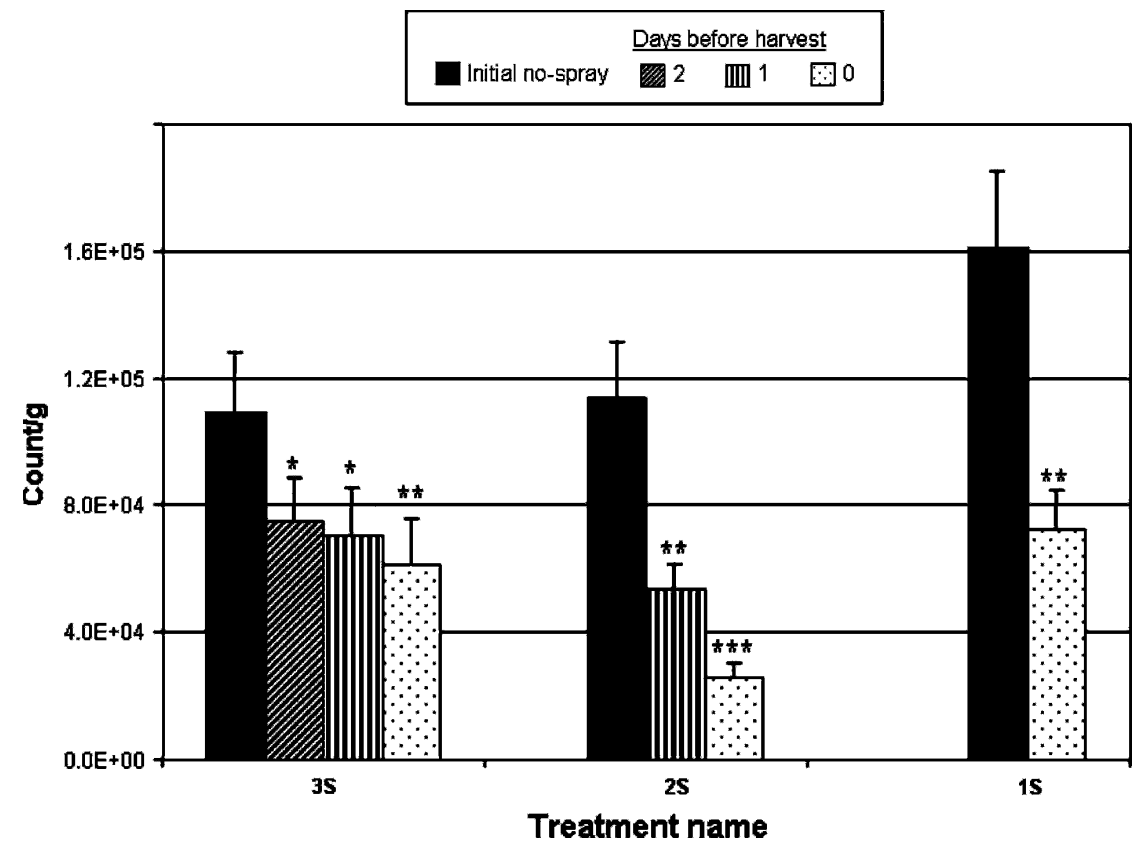

Fig. 3. Numbers of microorganisms counted (cfu/g) on immature fruit surfaces before (solid bar) and after spraying 3 (3S), 2 (2S), and 1 (1S) d preharvest. Data are means of four bags containing five strawberries each. Stars indicate significant differences between initial unsprayed plants (first column, solid bar) and sprayed berries 2,1 , and $0 \mathrm{~d}$ before harvest of ripe berries: ${ }^{* * * * * * * *}$ significant at $P \leq 0.05$, $0.01,0.001$, respectively. however, PAA has no effect or may even be damaging to ripe strawberries. If trichomes of the strawberries were damaged, it would result in increased infection. The high acidity of the combined pre- and postharvest PAA treatments may have damaged these structures. Discs with PAA in $B$. cinerea plates maintained areas of reduced or no growth (zones of inhibition) even after $10 \mathrm{~d}$ (Fig. 4).

Significance of results. All strawberries in these experiments were held at abusive temperatures (warmer than commercial storage) (Mitcham and Mitchell, 2002) to accelerate decay and simulate possible temperature abuse in transit or in consumer kitchens. Many studies have shown that cooling after harvest and in storage is important for extending shelf life (El Ghaouth et al., 1991; Maas, 1980; Nunes et al., 2002). In this study, at temperatures above storage optimum, strawberries sprayed $3 \mathrm{~d}$ preharvest had significantly less decay than strawberries sprayed $1 \mathrm{~d}$ before harvest or nonsprayed at some point of time in storage. The majority of decay in the stored fruit in this study was incited by $B$. cinerea followed by $R$. stolonifer. These organisms are the most problematic postharvest pathogens on strawberries (Blacharski et al., 2001; Bristow, 1986; Maas, 1980; Maas and Smith, 1972). Studies suggest that $B$. cinerea gains entrance into the strawberries in the field, remains latent, and causes decay after harvest (Bristow, 1986; Maas, 1980). Suggested controls include preharvest fungicide sprays at the prebloom, flowering, or young fruit stage (Blacharski et al., 2001; Maas, 1980; Maas and Smith, 1972). The prophylactic activity of the fungicide decreases the spores of $B$. cinerea that can invade young tissues. $R$. stolonifer is more difficult to control with field sprays because it is a wound pathogen and ripe fruit offer a good substrate (Maas, 1980).

PAA is a strong oxidizer and reduces microbial spore populations on fruit surfaces (Narciso, 2005). When PAA was sprayed on flowers and young fruit, spore numbers were reduced on surfaces, so fewer spores germinated and infected young tissue, reducing decay in fruits that were allowed to ripen (Fig. 3). Plants that were sprayed $3 \mathrm{~d}$ preharvest had only flowers and very young fruit (all ripe strawberries were harvested before the initial spraying). Our storage data show that decay was generally significantly reduced when PAA was sprayed on flowers and young fruit when compared with PAA sprays on ripe (1S groups) or nonsprayed strawberries (Figs. 1 and 2). Differences in results in onset of decay for storage studies from January through March could be attributed to changes in disease pressure in the field and the aging strawberry plants stressed by the increase in nighttime temperatures.

Other studies have also shown that $B$. cinerea and $R$. stolonifer spread in storage with fruit-to-fruit contact (Maas, 1980). In our clamshells, we found disease development on one or two stored strawberries that spread from the point of contact until all fruit 

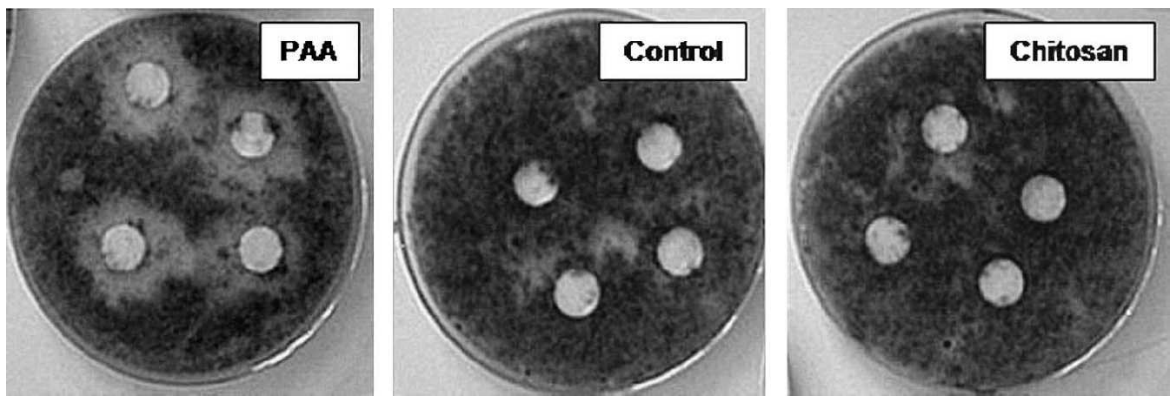

Fig. 4. Ten-day-old Botrytis cinerea cultures growing on potato dextrose agar plates with discs containing peroxyacetic acid, chitosan, and sterile water (control).
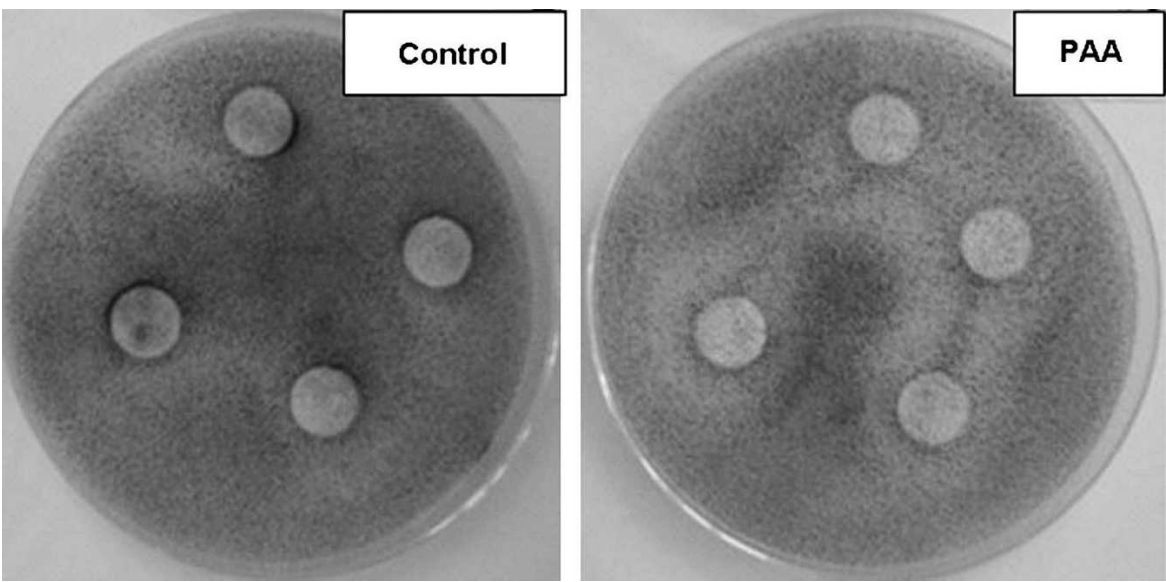

Fig. 5. Ten-day-old Rhizopus stolonifer cultures growing on potato dextrose agar plates with discs containing peroxyacetic acid and sterile water (control).

Table 1. Percent decayed fruit treated or not with a preharvest peroxyacetic acid $\left(100 \mu \mathrm{L} \cdot \mathrm{L}^{-1} \mathrm{PAA}\right)$ spray and treated postharvest with water, PAA, chitosan, or sodium (Na)-propionate.

\begin{tabular}{llllcc}
\hline & Postharvest & \multicolumn{4}{c}{ Days in storage at $18^{\circ} \mathrm{C}$} \\
\cline { 3 - 6 } Preharvest PAA & treatment & 4 & 6 & 8 & 12 \\
\hline No & Nothing & 2.5 & $55.0^{*}$ & 62.5 & 80.0 \\
Yes & Nothing & 0.0 & $15.0^{*}$ & 42.5 & 72.5 \\
No & Water & 0.0 & 57.5 & 72.5 & $100.0^{*}$ \\
Yes & Water & 2.5 & 52.5 & 77.5 & $87.5^{*}$ \\
No & PAA & 0.0 & 25.0 & 42.5 & 82.5 \\
Yes & PAA & 10.0 & 40.0 & 52.5 & 67.5 \\
No & Chitosan & 0.0 & $77.5^{*}$ & $87.5^{*}$ & $97.5^{*}$ \\
Yes & Chitosan & 0.0 & $12.5^{*}$ & $17.5^{*}$ & $55.0^{*}$ \\
No & Na-propionate & 5.0 & 52.5 & 70.0 & 72.5 \\
Yes & Na-propionate & 0.0 & 22.5 & 40.0 & 80.0 \\
\hline
\end{tabular}

${ }^{\mathrm{z}}$ Numbers are percent decay of 40 fruit. Means followed by an asterisk indicate significant differences $(P \leq$ 0.05 ) between preharvest PAA-treated and nontreated fruit within a postharvest application treatment and day in storage using the Wilcoxon two-sample test (or the Kruskal-Wallis test).

$\mathrm{PAA}=$ peroxyacetic acid

in the clamshell were involved. A preharvest treatment to reduce spores and a postharvest antimicrobial treatment to reduce in-storage spread of decay organisms would seem an ideal system to lengthen shelf life of these fragile fruit.

At a $100 \mu \mathrm{L} \cdot \mathrm{L}^{-1}$ solution, PAA was not phytotoxic on leaves, flowers, or fruit. Pollinating insects were not deterred from flowers just sprayed (data not shown). Because U.S. Environmental Protection Agency field allowances for PAA are higher than what we used in this study, future work will involve testing increasing concentrations of preharvest PAA applications for better postharvest decay control. Times of applications, as well as assessing ripening strawberries for both their microbial loads and the effectiveness of PAA on these loads, will be further studied. Peroxyacetic acid could be used to complement other methods of decay control presently in use by reducing the use of fungicides in the field if they were alternated with PAA sprays.

Studies with postharvest treatments on strawberries previously sprayed with PAA showed variable results. In most cases, the addition of a coating or surface treatment did not lengthen storage time of the fruit with the exception of the chitosan coating. The activity of the PAA and surface treatments needs further analysis to identify combined pre- and postharvest treatments that will most effectively maintain strawberry quality.

\section{Literature Cited}

Blacharski, R., J. Bartz, C. Xiao, and D. Legard. 2001. Control of postharvest Botrytis berry rot with preharvest fungicide applications in annual strawberry. Plant Dis. 85:31-39.

Bristow, P. 1986. Infection of strawberry flowers by Botrytis cinerea and its relevance to grey mold development. Ann. Appl. Biol. 109: 545-554.

El Ghaouth, A., T. Arul, C. Wilson, and N Benhamon. 1997. Biochemical and cytochemical aspects of the interactions of chitosan and Botrytis cinerea in bell pepper fruit. Postharvest Biol. Tech. 12:183-184.

El Ghaouth, A., J. Arul, J. Grenier, and A. Asselin. 1992. Antifungal activity of chitosan on two postharvest pathogens of strawberry berries. Phytopathology 82:398-402.

El Ghaouth, A., J. Arul, R. Ponnampalam, and M. Boulet. 1991. Chitosan coating effect on storability and quality of fresh strawberries. J. Food Sci. 56:1618-1631

Karabulut, O., U. Arslan, and G. Kuruoglu. 2004 Control of postharvest diseases of organically grown strawberries with preharvest applications of some food additives and postharvest water dips. J. Phytopath. 152:224-228.

Kendra, D.F. and L.A. Hadwiger. 1984. Characterization of the smallest chitosan oligmer that is maximally antifungal to Fusarium solani and elicits pisatin formation in Pisum sativum. Exp. Mycol. 8:276-281.

Maas, J. and W. Smith. 1972. Preharvest fungicide treatments for increasing yields and controlling pre and post harvest berry decay of strawberry. Plant Dis. Rptr. 56:296-299.

Maas, J. 1980. Postharvest diseases of strawberries, p. 329-353. In: N.F. Childers (ed.). The strawberry. Horticultural Pub., Gainesville, Fla.

Mitcham, E.J. and F.G. Mitchell. 2002. Postharvest handling systems: Small fruits, strawberries and cane berries, p. 364-370. In: A.A. Kader (ed.). Postharvest technology of horticultural crops. University of California Agriculture and Natural Resources, Publication \#3311.

Narciso, J. 2005. An assessment of methods to clean citrus fruit surfaces. Proc. Fla. State Hort. Soc. 118:437-440.

Narciso, J. and A. Plotto. 2005. A comparison of sanitation systems for fresh-cut mango. HortTechnology 15:837-842.

Nunes, M.C.N., A.M.M.B. Morais, J.K Brecht, and S.A. Sargent. 2002. Fruit maturity and storage temperature influences response of strawberries to controlled atmospheres. J. Amer. Soc. Hort. Sci. 127: 836-842.

Park, S., S. Stan, M. Daeschel, and Y. Zhao. 2005. Antifungal coatings on fresh strawberries (Fragaria Xananassa) to control mold growth during cold storage. J. Food Sci. 70: 202-207.

Sholberg, P., P. Haag, R. Hocking, and K. Bedford. 2000. The use of vinegar vapor to reduce postharvest decay of harvested berry. HortScience 35:898-903.

State of Florida. 2006. Florida automated weather network. Jan.-March 2006. <http://fawn.ifas. ufl.edu>.

U.S. Dept. of Agriculture. 2005. Berry and tree nut outlook/FTS-317: 28 July 2005. Economic Research Service, U.S. Dept. of Agr., Washington, D.C.

Wu, X., G.R. Beecher, J.M. Holden, D.B. Haytowitz, S.E. Gebhardt, and R.L. Prior. 2004. Lipophilic and hydrophilic antioxidant capacities of common foods in the United States. J. Agr. Food Chem. 52:4026-4037. 